\title{
Plantation Indigo and Synthetic Indigo: European Planters and the Redefinition of a Colonial Commodity
}

\author{
PRAKASH KUMAR \\ History and Asian Studies, Pennsylvania State University
}

The rise of indigo plantations in colonial Bengal paralleled the consolidation of British rule on the Indian subcontinent from the last quarter of the eighteenth century. These colonial plantations were an embodiment of the project of agricultural "improvement"1 under the imperial umbrella and a manifestation of the working of colonial capital and appropriation of peasant labor. The indigo this complex produced was a major source of supply of blue dye for textile

Acknowledgments: Several people helped me with key citations and ideas during the writing of this paper. I would like to thank for their valuable input Ruth Alexander, Maxine Berg, Ann Little, John McNeill, Joel Mokyr, Jared Orsi, and Andrea Williams. This paper was first presented at a faculty colloquium at Colorado State University, and was further developed drawing on feedback I received at the annual meetings of the History of Science Society in Cleveland and the American Society for Environmental History in Washington, D.C. Finally, I am grateful to the $C S S H$ reviewers for their very useful comments and to Andrew Shryock for patiently shepherding this article through the long review process.

${ }_{1}$ Scholars have variously studied colonial improvement as an ideology and framework for policy, action, and control, whether in the context of its roots in European enlightenment thought, or in specific tropical and colonial contexts. Richard Drayton, Nature's Government: Science, Imperial Britain, and the 'Improvement' of the World (New Haven: Yale University Press, 2000); David Arnold, The Tropics and the Traveling Gaze: India, Landscape, and Science, 1800-1856 (Delhi: Permanent Black, 2005). For the pursuit of improvement as a societal goal, see Thomas Metcalf, The New Cambridge History of India, Ideologies of the Raj (New York: Cambridge University Press, 1995), 17. Metcalf states, “....by the end of Lord Cornwallis's years as governor-general (1786-1793), the British had put together a fundamental set of governing principles. For the most part these were drawn from their own society, and included the security of private property, the rule of law, and the idea of 'improvement."' Peter Robb, and more recently David Arnold, have extended the study of improvement as an idealized goal to the topic of agriculture: Peter Robb, "British Rule and Indian Improvement," Economic History Review 34, 4 (Nov. 1981): 507-23; "Bihar, the Colonial State and Agricultural Development in India, 1880-1920," Indian Economic and Social History Review 25, 2 (1988): 205-35, esp. 205-7; David Arnold, "Agriculture and 'Improvement' in Early Colonial India: A Pre-History of Development," Journal of Agrarian Change, 5, 4 (Oct. 2005): 505-25. For a study of the empire's tapping into local landscapes and labor to convert forests into tea "gardens" in the Nilgiri hills and in colonial Assam, see Kavita Phillip, Civilizing Natures: Race, Resources, and Modernity in Colonial South India (New Brunswick: Rutgers University Press, 2003); and Jayeeta Sharma, Empire's Garden: Assam and the Making of India (Durham: Duke University Press, 2011). 
manufacturing the world over throughout the nineteenth century. But at that century's turn, the colonial commodity, now produced chiefly in the districts of Bihar, ran into competition from a new, purer, and cheaper synthetic indigo produced in German factories. ${ }^{2}$ The new product fully changed the context and meaning of the project of colonial improvement, implemented in the face of a threat from a synthetic "substitute." The planters' efforts to improve the output and purity of agricultural indigo in the post-synthetic phase offers an opportunity to examine "improvement" and its relation to forces that were extra-imperial in origin and global in scale.

The colonial planters conducted scientific experiments and developed new selling strategies to save their product against synthetic indigo. They were defending not only their product, but also the plantation mode of production, and were resisting their own demise and deskilling that the industrial indigo bode. Forced to defend their product, the planters highlighted certain notions of purity as well as of color, potency, and value of the agricultural dye in order to differentiate it from synthetic indigo. Their constant probing of science's utility to the process of enhancing the agricultural dye and their deliberation of parameters for evaluating the market price of plantation indigo required navigating the muddled terrain of scientific rationality and market value. In doing so, the planters summoned up "nature" in specific ways, while questioning what agricultural indigo was and envisioning how and to what extent it could be enhanced. At stake was the definition of nature as it was embodied in indigo. The range of meanings that planters imputed to their dye amounted to visualizing society's relationship with nature in templates that ran against the new logic of the production, evaluation, and consumption of synthetic indigo. The plantation order was an embodiment of colonial modernity that had run afoul of the new industrial logic of the manufacture of synthetics. This paper examines planters' discordant voices as they tried to stall and reverse changes in modes of manufacturing during this period. My goal is to highlight colonial ideas about nature, industrialization, and the relationship between them.

AGRICULTURAL INDIGO MEETS A “SUBSTITUTE”

The indigo plantation of Bengal was a product of colonial discourse that was grounded in essentialisms of civilization and progress. Colonialists sought a social and moral order in the colony that would be economically advantageous

\footnotetext{
2 The epicenter of indigo plantations in the province of Bengal changed from the eighteenth to the nineteenth centuries. Indigo plantations were launched in Bengal's deltaic zones, the areas in the administrative division of Lower Provinces. From the mid-nineteenth century, however, there was a westward shift of plantations, triggered particularly by the "blue mutiny" of indigo growers against European planters in 1862-1864 that drove the indigo industry out of Lower Provinces. The plantations found a new home in the northern districts of Bihar, and that is where the European planters were chiefly based in the late nineteenth and early twentieth centuries.
} 
and politically expedient. The colonial initiative had purportedly turned unimproved landscapes in Bengal into Edenic "gardens" of productive use. Recently Jayeeta Sharma has explained the avocation of "order" in colonial discourses that defined plantations in opposition to unruly forests that were an imperfect embodiment of nature. ${ }^{3}$ Contrarily, when facing the threat of German artificial indigo, the planters in Bengal defended plantations by associating them with an essentialized order of pristine nature. They asserted that plantation indigo was a better product because of its agricultural form of production, pointing to the grounding of their methods of production in the layout of land and farming. In this argument, industrial indigo had introduced disruption into an acceptable method of producing the dye. This was a complication of the colonial discourse of improvement. The Bengal indigo was the product of choice for consumers worldwide, and the threat that synthetic indigo posed in this global market forced a reinvention of the discourse. ${ }^{4}$

The Bengal plantation was an imperial and colonial garden fully subservient to the economic and political interests of the colonialists. ${ }^{5}$ Indigo produced on the Bengal plantations was the fruit of contrived forms of colonial labor that returned a handsome profit to the planters. Planters of European descent used complex contract laws to obligate the peasantry to grow indigo for very low remuneration ${ }^{6}$ and they coerced local and migrant labor to produce the dye from the plant. $^{7}$ The premium quality indigo produced on

3 Sharma explains the colonial appropriation of tea gardens in Assam, adjoining Burmese territories, in the northeast of the India subcontinent, from the mid-nineteenth century. The colonialists applauded the element of utility and diligence as they turned Assam hillsides into a "commodityproducing garden-space." Jayeeta Sharma, Empire's Garden: Assam and the Making of India (Durham: Duke University Press, 2011), quote p. 5. For the colonial reinforcement of "difference" vis-à-vis forest dwellers - the "tribes of India"-in the project of improvement, see Ajay Skaria, "Shades of Wildness: Tribe, Caste and Gender in Western India," Journal of Asian Studies 56, 3 (1997): 726-45. For the colonial centering of forests as nature in emphasizing difference, see, K. Sivaramakrishnan, "British Imperium and Forested Zones of Anomaly in Bengal," Indian Economic and Social History Review 33 (1996): 225-42.

${ }^{4}$ For a similar complication of colonial discourses by imperial and extra-imperial forces, see Mrinalini Sinha's discussion of global debates around the publication of Katherine Mayo's Mother India that portrayed an essentialized Hindu character. Mrinalini Sinha, Specters of Mother India: The Global Restructuring of an Empire (Durham: Duke University Press, 2006).

${ }^{5}$ Bengal indigo was a prized commodity in colonial commerce. Benoy Chowdhury, Growth of Commercial Agriculture in Bengal, 1757-1900 (Calcutta: India Studies, 1964); Amales Tripathi, Trade and Finance in Bengal Presidency, 1793-1833 (Calcutta: Oxford University Press, 1979 [1956]).

6 Amiya Rao and B. G. Rao, The Blue Devil: Indigo and Colonial Bengal (Delhi: Oxford University Press, 1992), 48-60.

7 The element of coercion emerged particularly after the first quarter of the nineteenth century. Sugata Bose has identified 1825 as the cut-off point after which colonial capital clearly and directly acquired an aspect of extra-economic coercion, in The New Cambridge History of India, Peasant Labour and Colonial Capital: Rural Bengal since 1770 (Cambridge: Cambridge University Press, 1993), 47. See also, Benoy Chowdhury, Growth of Commercial Agriculture in Bengal, 1757-1900 (Calcutta: Quality Printers, India Studies, Past and Present, 1964); Amiya Rao and B. G. Rao, The Blue Devil: Indigo and Colonial Bengal (Delhi: Oxford University Press, 1992); Jacques 
the backs of colonized workers was sold to textile manufactories in the metropolis and other parts of the world, bringing enormous profits to the European planters and their managerial staff, as well as to a network of European shippers, insurers, bankers, and brokers.

The blue color lodged in the indigo plant's leaves was recovered through an intricate production process. The plant matured over three to four months, at which point planters had the leaves separated from the stalk, sorted, and sent to centralized "factories" that they owned. These factories were scattered over the plantations, and each consisted of a series of large vats used to convert the leaves into a dye. In the first vat leaves were drenched in water and fermented. The fermented liquid was then transferred to a second vat in which it was beaten and stirred to facilitate oxidation. The color eventually emerged from the mix of pulp and water and descended to the bottom of the tank. This was washed and purified in a third vat, after which the blue dye was dried and cut into standard-size cakes that were shipped to dyeing houses in the West.

The advent of synthetic indigo in 1897 and the claim that it was a viable "substitute" brought into question the basic premise of the plantation mode of production. Synthetic indigo was produced from chemicals and represented a new type of manufacturing in the era of the second industrial revolution. ${ }^{8}$ It was derived by operationalizing a chemical pathway on an industrial scale through which an abundant and inexpensive coal-tar derivative, naphthalene, was converted into synthetic indigo. Furthermore, while plantation indigo's constitution was never a constant, the new product was of uniform concentration. In subsequent years, synthetic indigo manufacturers managed to lower the cost of its production, and its consistency and cheapness drew consumers away from agricultural indigo.

But even as synthetic indigo continued to make inroads into the market, not all stakeholders recognized its superiority. There was no unanimity over what a good dye was or whether synthetic indigo's purity and consistency were advantageous in every case. It also remained an open question whether the cheaper synthetic indigo allowed for as much dyeing as agricultural indigo of equivalent price, which left the issue of ultimate value to the purchaser unsettled. Pitted against structural forces, the planters were befuddled, but stood their ground. They made contesting claims on the qualities of agricultural indigo based on its origins among plants, and thereby questioned the basis upon

Pouchepadass, Champaran and Gandhi: Planters, Peasants and Gandhian Politics (Delhi: Oxford University Press, 1999).

${ }^{8}$ Scholars have commented that the Second Industrial Revolution in the latter half of the nineteenth century was characterized by its reliance on new, complex sciences of chemistry and electricity. The dye industry in particular was invigorated by the incorporation of organic chemistry into factory-based manufacturing. The most vivid representation of this new trend appeared in the rise of the synthetic dye industry in Germany. 
which the market had come to place a higher value on the traits of synthetic indigo. Under duress, planters put forth a vision that was grounded in a specific meaning of nature.

\section{THE NATURALNESS OF AGRICULTURAL INDIGO}

In the early twentieth century, as planters became alarmed by the threat of synthetic indigo, their emphasis on the naturalness of agricultural indigo assumed a new significance. ${ }^{9}$ There is no doubt that the planters had emphasized indigo's naturalness to bolster their claims that it was the only "true" blue dye. Now, faced with an alternative, they were finding it necessary to further emphasize its naturalness. Though this argument was self-serving, it was nonetheless pregnant with deeper meanings of epistemic significance, and it invites us to investigate the distinct knowledge regime that the planters were trying to resurrect.

Two essays written at the turn of the century by Frederick Mollwo Perkin, an eminent British chemist and public figure, serve as a convenient starting point for studying how the naturalness of agricultural indigo came to be defined. In the first essay, published in Nature in 1900, Perkin expressed indignation at the planters' constant refrain of "real indigo dye and German imitation." He said he was at a loss to understand such a distinction, which planters made through allusions to plantation indigo's authenticity. ${ }^{10}$ Two months later, Perkin wrote again in the same preeminent journal, this time echoing the call of L. J. Harrington, a planter based in Bengal, that if planters were to prevail over synthetic indigo they needed to engage "not one chemist, but a dozen." 11 Harrington commended their engagement several months before of the chemist Christopher Rawson, ${ }^{12}$ and underscored the view that scientists could revamp the agricultural indigo produced in Bengal and lower its price. Perkin added his own voice to this call for planters to look to science to enhance their product's value.

The planters' insistence that agricultural indigo was the "real" indigo and their simultaneous willingness to engage scientists to alter the natural dye captures their nuanced approach to science's ability to refurbish agricultural

9 An astute observer of indigo industry pointed out as late as mid-1903, referring to the depleted warehouse stocks of agricultural indigo, that despite the additional supplies of synthetic indigo since 1897, "The world's consumption has absorbed all kinds of indigo," both synthetic and agricultural. He further stated that a contraction in the overall supply of agricultural indigo from India was due to Lower Bengal districts having completely ceased production. The core districts of north Bihar apparently continued to produce indigo until much later, but gradually even these districts found themselves threatened with elimination from the market. "Vegetable Indigo," Indian Planters' Gazette, 9 May 1903: 660-61, 660 (first published in Englishman).

10 F. Mollwo Perkin, "The Present Condition of the Indigo Industry," Nature 63, 1622 (20 Nov. 1900): 111-12, 112 (his italics).

11 F. Mollwo Perkin, “The Present Condition of the Indigo Industry,” Nature 63, 1630 (24 Jan. 1901): 3012-13, 3013.

${ }^{12}$ Christopher Rawson's letter to the Indigo Defence Association, 28 Feb. 1898, Bihar State Archives, Patna, India, Agriculture, file 2I/3, Mar. 1901. 
indigo. To be accurate, a few planters and their supporters would later fundamentally object to seeking the counsel of professional scientists. But as a body of the indigo manufacturing and trading class organized within the Bihar Indigo Planters' Association (BIPA), the planters made an early decision to engage scientists. In the years that followed their engagement of Rawson, they employed chemists, bacteriologists, biologists, experts on breeding, and agricultural experts. But the planters embraced science on terms favorable to the agricultural dye, and their scientists applied themselves to developing more potent lines of the indigo plant, increasing the yield from the manufacturing process, and improving the blue color by removing earth, twigs, and other unwanted elements. The planters were willing to dabble in science in order to differentiate their product from the other "scientizing" of the dye embodied in the industrial manufacture of synthetic indigo. At no point did they cede ground to the industrial product by acknowledging that it was a true substitute.

Planters' own scientists clarified the nature of the contest quite early on. In an internal report to the members of the BIPA in 1901, the lead chemist Rawson recounted that, in the past, coal-tar dye manufacturers had offered countless artificial blue dyes in the market, but that these dyes, made from coal-tar derivatives, were "inferior imitations." However, he pointed out, a key shift had occurred when "indigotin itself produced synthetically was put upon the market." ${ }^{13}$ Rawson's observation was in line with the understanding on the plantations that plant indigo dye was comprised of two primary coloring elements: indigotin, which provided the primary blue color; and indirubin, a substance that gave the dye an additional red sheen. All agreed that the agricultural dye also contained residual elements such as indigo brown, water, indigo gluten, minerals, and resins.

However, the planters vehemently contested the claim that "indigotin," once synthesized and sold in the form of synthetic indigo, could be a substitute for agricultural indigo. In their view, synthetic indigo was "synthetic indigotin," a popular appellation by which they consistently referred to the new industrial product. This perspective was given voice by the planter Keith MacDonald, who noted in the planters' trade magazine, “...there is not such a thing as artificial indigo. What is meant [by that expression] is synthetic indigotin produced from the derivatives of coaltar, a very different thing." The planters saw the blue dye produced on the plantations as superior due to the quality that all of its constituents, not just indigotin, provided to it. There was therefore no basis for synthetic indigo manufacturers to claim any kind of parity with agricultural indigo, and MacDonald chided them for seeking it, remarking, "One might as well call albumen an egg or starch a potato as to call synthetic

13 "The Prospects of Natural Indigo by Christopher Rawson, F.I.C.," B. P. Association Press Mozufferpore, 17 Feb. 1901, Bihar State Archives, Patna, India, Agriculture, File 2I/3, Mar. 1901. 
indigotin, indigo!" 14 This refrain had staying power on the plantations; writing in 1910, when the plantation industry in colonial India was on its last legs, one planter attributed this sad state primarily to the "indgotin [sic] lie." He meant that by successfully projecting the "lie" that synthetic indigotin was equivalent to "indigo," backers of the synthetic product had brought the plantations to ruination. ${ }^{15}$

The legitimacy that planters sought for agricultural indigo through their allusions to its composite nature hinged on assertions about the natural state of things. MacDonald elaborated that agricultural indigo was "an organic compound body which contains several other ingredients and colors besides indigotin, and it is the combination that gives natural indigo pre-eminence over all other blue colours." This was how nature had ordained the blue dye to be-an amalgamation of various constituents that were blended harmoniously through nature's force. They reiterated the same point through a religious allusion, saying that agricultural indigo was a product of "incessant work going on in the cells of the plant-God's laboratory"-which could not be matched by synthetic indigo concocted in "a chemical laboratory." ultimate reference to nature that the planters tried to convince everyone of the superior claims for plantation indigo.

The reality was that indigo, the blue dye, did not automatically ooze out of the indigo plant - it did not exist in a natural state. ${ }^{17}$ Rather, to get it the planters employed a streamlined manufacturing procedure that involved systematically processing leaves in modern, large-scale establishments located on the plantations, which were in fact called "factories." In other words, the planters' pastoral ideal accommodated the mechanization that the plantation subsumed within

14 Keith MacDonald, letter to the editor, Indian Planters' Gazette, 26 Oct. 1907: 520. This journal is held in the National Agricultural Library, Beltsville, Maryland.

15 “Indigo and Common Sense," Indian Planters' Gazette, 9 July 1910: 67-68.

16 Keith MacDonald, letter to the editor, Indian Planters' Gazette, 7 Dec. 1907: 704 (his italics).

17 What exactly constitutes a "natural state" is, of course, a complex question. Environmental historians have provided valuable insights into how best to deploy "nature" in a reflexive way without falling to the perils of determinism. While nature in environmental studies frequently appears as constructed or socially produced, the concept of a pristine, untouched nature that existed at some point deeper in history often lurks. If nothing else, it appears as a constant referent in discussing the impact of social action on the environment. The notion of a pristine nature is also salient in writings that highlight the natural world's history as apart from human influences. See Donald Worster's treatment of the "arcadian ideal" in ecological worldviews. In the preface to the new edition of this important work he subtly acknowledges his intellectual agenda of uncovering the autonomy of nature, asking the fundamental question: "whether nature has an order, a pattern, that we humans are bound to understand and respect and preserve." Nature's Economy: A History of Ecological Ideas (Cambridge: Cambridge University Press, 1977), ix. See also William Cronon's distinction between "first" and "second" nature, in which he identifies the former with a pre-human nature later altered by human interaction with nature. Nature's Metropolis: Chicago and the Great West (New York: W. W. Norton, 1991), 56, passim. For a review of the theoretical stakes in this debate, see Kristin Adal, "The Problematic Nature of Nature: The PostConstructivist Challenge to Environmental History," History and Theory, Theme Issue 42 (Dec. 2003): 60-74. 
itself. The plantation was, in their view, what Leo Marx has called "the machine in the garden," and they defended this "society of the middle landscape" that reflected "a happy balance of art [standing for technic] and nature." "18 Over the course of the nineteenth century, European planters in Bengal embraced mechanization, steam power, and the use of chemical substances at a faster pace than ever before. The result was a progressively more systematic, efficient, and intrusive method of extracting the dye, and in reality extracted indigo made a poor symbol of anything prior to human intervention in nature's scheme of things.

In calling agricultural indigo "natural," however, the planters were espousing something broader: a claim for the naturalness of the entire plantation system of manufacturing. They were extending an argument about the foundational unity and character of the blue dye, that it was already present in a complete and finished form in the indigo plant. In this view, the planters' methods simply involved removing the dye from the leaves without disrupting its internal unity. Therefore, the growing of indigo on managed estates and its processing in vats were respectful of nature and represented a natural system of manufacturing.

In the end, their argument for agricultural indigo's naturalness was a defense of the plantation ethos and mode of production against a competing system of production in the German factories. The disdain for the "chemical laboratory" apparent in MacDonald's verdict hardly reflected a total disavowal of science per se; it was rather a critique of the placement of science, particularly chemistry, in the new industrialism. While the first industrial revolution had radically transformed textile manufacturing from an artisanal mode to a factory-based one, it had left unscathed the dyes used. It remained dependent on colors and colorants extracted from plants and minerals. In other words, dyes were in this sense still "naturally produced." The second industrial revolution, with its massive reliance on chemistry - just one aspect of the new relationship between industrialism and science $^{19}$ - brought a new logic of manufacturing that also began to pervade the world of dyes and colorants. The planters were left to defend their erstwhile system of producing dyes from plants.

18 Leo Marx, Machine in the Garden: Technology and the Pastoral Ideal in America (New York: Oxford University Press, 1964 [repr. 1981]), quotes 226.

19 Joel Mokyr examines the seminal importance of science in the second industrial revolution, highlighting the roles of chemistry and electricity: The Lever of Riches: Technological Creativity and Economic Progress (New York: Oxford University Press, 1992), ch. 6, 113-50. For an older work with a similar focus, see David Landes, The Unbound Prometheus: Technological Change and Industrial Development in Western Europe from 1750 to the Present (Cambridge: Cambridge University Press, 1969), 193-358. For a review of the rise of the chemical industry in the West, see L. F. Haber, The Chemical Industry during the Nineteenth Century (Oxford: Clarendon Press, 1958, repr. 1969); and The Chemical Industry, 1900-1930 (Oxford: Clarendon Press, 1971). For the promotion of chemistry by the state in Germany, see Jeffrey Johnson, The Kaiser's Chemists: Science and Modernization in Imperial Germany (Chapel Hill: University of North Carolina Press, 1990). 


\section{NATURAL INDIGO IN THE MARKET}

It was one thing for the planters to insist upon a particular definition of the agricultural dye and quite another to persuade the market to value the product as per that definition. To be sure, there was no dearth of agricultural indigo loyalists willing to argue the case for plantation indigo. It was the reigning dye, with an established infrastructure of traders, brokers, and sellers, and these backers made the case for it on two main counts. First, they challenged the methods of valuation in the market according to which a price was fixed for plantation indigo. Second, they conducted a public demonstration, a comparative dyeing trial, at a textile factory in Cawnpore, India intended to persuade everybody of their product's superior dyeing powers.

\section{Calling for a Different Science}

If science is a representation of reality, ${ }^{20}$ then two realities became embroiled as the struggle between plantation and synthetic indigo unfolded. The market became their battleground as agricultural indigo backers demanded a new system of valuation or testing. Their contention was that the tests analytical chemists used to fix the market price of plant-derived indigo were flawed because they could not properly assess its unique qualities. In a quest to emphasize their commodity's merits, the planters and their representatives called into question the science of these tests.

Professional, analytical chemists only became involved with the indigo trade from the last quarter of the nineteenth century. These trained personnel specialized in testing dye to measure its color and set its price accordingly. Such testing replaced earlier valuation methods used by buyers, who had always evaluated the dye according to its texture, amenability to grinding, appearance (a good dye was bright blue whereas a slaking texture and darkish black color indicated faulty manufacturing and poor quality), weight (the best quality was supposed to float in water), and level of contamination with earthly materials. Indian indigo was known to vary greatly in its coloring potential depending upon the region in which it had been produced, the

${ }^{20}$ Science and Technology Studies (STS) scholars have clarified the ways scientists generate truth about the natural world, thus conjuring science as a representation of nature and not a reflection of an ultimate reality. Within the latter tradition, actor network theoreticians have conceptualized the existence of "networks" within which, they insist, nature, culture, and science are so entangled that it makes no sense to treat any one of them as prior or causative. Bruno Latour and Donna Haraway made the case for conceptually fusing society and nature for analytical purposes, the former by giving agency to non-humans and the latter by envisioning the existence of "hybrids." See Bruno Latour, The Pasteurization of France, Alan Sheridan and John Law, trans. (Cambridge: Harvard University Press, 1988); and Reassembling the Social: An Introduction to Actor-Network-Theory (New York: Oxford University Press, 2007); Donna Haraway, Simians, Cyborgs and Women (New York: Routledge, 1991); and Modest Witness@ Second Millennium (New York: Routledge, 1997). For a later treatment of actor network theory, see John Law and John Hassard, eds., Actor Network Theory and After (Oxford: Blackwell, 1999). 
workmanship of manufacturing, and its upkeep and transport. The reputations of different marks also fetched them different prices. The new class of professional analysts began to additionally subject indigo imported from India to reductive chemical tests to determine the percentage of color in the dye. Increasingly, indigo's market value began to be fixed by chemists' determinations of color percentages. The subjective criteria of the earlier valuation regime were not completely discarded, but the analysts and their chemical tests assumed a new importance.

In the synthetic indigo era, this system of evaluation based on percentages became detrimental to the planters' efforts to compete in the market. The new chemistry of European science could represent the substance indigo with a formula, and the German synthetic indigo manufacturers claimed that their artificial dye was solely indigo, which they sold in a 20 percent concentration. ${ }^{21}$ The system of mathematical proportionality and precision in transactions reflected a new science that was applicable to organic products generally and the same principles operated in the dye trade. ${ }^{22}$ In the testing regime of percentages the Bengal indigo was purported to contain on average about 60 percent indigo. A unit weight of 20 percent concentration synthetic indigo was considered equal in value to one-third the weight of plantation indigo containing 60 percent indigo. Synthetic and natural producers disagreed as to the utility of the other 40 percent, which consisted of constituents in the plantation dye such as indigo brown, water, indigo gluten, minerals, and resins. The synthetic manufacturers claimed that these elements were useless to the dyeing process and thus counted them as "impurities," while natural dye producers argued that they had tinctorial value.

The planters worked to counter the understanding promoted by percentage tests. BIPA Secretary T. R. Filgate insisted in a note in the trade newspaper that a pound of natural indigo was equivalent to 5 pounds of synthetic indigo because the latter was sold in a 20 percent concentration. In Filgate's understanding, all of the natural dye was indigo, leaving no room for distinctions between color and the so-called impurities. But such assertions clashed with the dominant system of setting market prices. Thus Jules Karpeles, a broker of Bengal indigo in the London markets, tried to correct Filgate's equation between a unit-weight of natural indigo and five times its weight of synthetic

21 That Adolf Baeyer in August 1883 first drew the modern structural formula of indigo is evident in his personal communication with BASF's Heinrich Caro. Carsten Reinhardt and Anthony Travis, Heinrich Caro and the Creation of Modern Chemical Industry (Dordrecht: Kluwer, 2000), 200-1.

22 For the rise of organic chemistry, see Alan J. Rocke, The Quiet Revolution: Hermann Kolbe and the Science of Organic Chemistry (Berkeley: University of California Press, 1993). For infiltration of new chemistry into the field of agricultural sciences and their application in trade, see E. J. Russell, A History of Agricultural Science in Great Britain, 1620-1954 (London: George Allen \& Unwin, 1946). 
indigo (20 percent). He wrote to remind Filgate that his communication had allowed an "inaccurate statement to slip in." Karpeles pointed out that, in reality, one pound of synthetic indigo of 20 percent concentration was selling at 9 pence and a pound of 63 percent agricultural indigo at 36 pence (and not just over 45 cents, as per Filgate's calculation), and that even at 36 pence it was perceived to be expensive for the amount of color it contained. He implied that market transactions were dominated by percentage tests. Karpeles said that he was sympathetic to the planters' argument that such a valuation system was unfair, and he acknowledged that some consumers did not believe in such tests, but of these so-called agricultural indigo loyalists he wrote, "They are unluckily very few!"23

The planters made a spirited campaign for the adoption of alternative "dye tests" that measured a dye's coloring power rather than belaboring its constitution. This was based on the claim that ingredients other than indigotin were also instrumental in giving color, and implicitly on additional, interconnected claims regarding functionality: that some elements in agricultural indigo were important in fixing the color onto fabric, and that the indigo-red in their dye gave garments a unique red sheen. But overall, they pinned their hopes to dye tests that they believed could prove plantation indigo was the stronger dye. Such was their trust in these tests that one sarcastically asked fellow planters to "stop stargazing at Sirsiah," one of the stations where scientific experiments were apace to improve agricultural indigo, and instead "establish a planters' testing station" that would be much more beneficial from a trade perspective. He asked for a chemical test valuator and a dye test valuator to work "side by side" so that the merits of agricultural dye could be proven. ${ }^{24}$

The planters' worldview was philosophically distinct from the rationalistic perspective that preferred identifying and measuring components of the dye, and it evidently removed mathematical rationality from evaluative measures. Their ideas about assays and testing resembled the late eighteenth-century Romantic sciences that, historians have argued, sought to bridge the gap between man and nature and the fragmentation of human faculties. ${ }^{25}$ In its larger implications, such a belief countered brute ordering in matters of exchange. It showed a preference for basing exchange on a commodity's organic unity and wholeness, a distinct view of the world and things, and its aesthetic beauty rather than its uniformity and predictability. In the making of commodities, it tendered a vision of the relationship between humans and nature as one that was wholesome and organic rather than dyadic.

\footnotetext{
${ }^{23}$ Jules Karpeles' letter to T. R. Filgate, 2 Jan. 1907, Indian Planters' Gazette, 23 Feb. 1907: $236-37$.

24 "On the Potassium Permanganate Titration and other Tests for Determining the Value of Indigo,” Indigo Planters' Gazette, 19 Mar. 1910: 511-14, 514.

${ }^{25}$ Andrew Cunningham and Nicholas Jardine, eds., Romanticism and the Sciences (Cambridge: Cambridge University Press, 1990), 1-9.
} 


\section{Demonstrating Better Value}

The planters weighed their options before deciding how to approach consumers with their point of view. They seem to have understood the complex nature of the market for blue dye, and as they planned their economic pitch they ably distinguished between end-users - the textile-using public - and the commercial consumers - the dyers and printers. Speaking about the textile buyers at large, indigo supporter Keith MacDonald noted, "The general public are [sic] quite indifferent to the virtues of natural ... indigo." ${ }^{26}$ This was to some extent an admission that, where actual garment users were concerned, planters had failed in pushing their argument regarding quality and aesthetics. He also referred to the buyers' inability to get correct information about the exact dye used in manufacturing. When these consumers wanted to buy garments dyed with natural indigo, and MacDonald believed many did, sellers instead sold them ones dyed with concoctions of different blue dyes both natural and artificial. He argued that those who demanded naturally dyed fabrics were being duped by dyers and printers selling synthetic indigo. Planters made muted demands that textile manufacturers be compelled to label their products to disclose the specific dyes used, but they failed to persuade the metropolitan government to impose such a regulation. Individual textile customers were a disparate group and were commonly unable or disinclined to execute their choices in the market, and the planters perceptively recognized their limitations in this regard. In the end they did not push the taste and quality argument with the textile users.

Instead, they invested their efforts in making a distinct economic plea of "value" to commercial buyers - the dyers and printers. They argued that more color could be derived from agricultural than synthetic indigo of equal weight, after adjusting for the percentages of indigotin in each. The planters thus asserted that it was more economical to work with plantation indigo even if one abided by the determinations of percentage tests. This was the age of commercial dyeing and printing on a large scale, and so if they could demonstrate even a marginal savings from working with agricultural indigo then the market might be won back. ${ }^{27}$ The planters' most notable intervention in this regard was their organization of a significant public demonstration that compared agricultural and synthetic indigos. In what became widely and popularly known as the Cawnpore trial-after Cawnpore Textile Mills in the neighboring United Provinces - the planters arranged for a spectacle to show one and all that it was cheaper to use their product. Given their resources, this was a reasonable

${ }^{26}$ Keith MacDonald, letter to the editor, Indian Planters' Gazette, 7 Dec. 1907: 704.

${ }^{27}$ For a study of new business patterns in the context of dyes, see work by the economic historian Alexander Engel, "Selling Indian Indigo in Traditional and Modern European Markets, 17801910," in Hartmut Berghoff, Phil Scranton, and Uwe Spiekermann, eds., The Rise of Marketing and Market Research (Houndmills: Palgrave, 2012), 27-47. 
way to reach out to the widest possible circle of dyers and printers. A public spectacle would both bring transparency and gain maximum, widespread impact through word of mouth and other informal channels.

The Cawnpore trial drew on the legitimacy of both science and industrial practice to push the planters' case. They had carefully chosen the platform of a textile mill and invited scientists and industrial dyers to conduct the trial, which was supervised by one of the planters' scientists, Cyril Bergtheil. A scientist of international credibility, Bergtheil supported the planters' claims for natural indigo. He believed in the percentage theory and yet asserted that plantation indigo gave more color than synthetic indigo when equivalent weights containing the same percentage of indigotin were used. His extensive laboratory experiments had confirmed just that. He said he was repeating these experiments as public trials "under absolutely practical conditions." These trials were therefore scientific experiments, and planters were exploiting the legitimacy of the empirical realism through which science was known to establish truth. ${ }^{28}$

The deliberate emphasis on "practical conditions" was equally pertinent; what better platform than a textile mill from which to stage a trial to persuade dyers and printers? To assist with the trial the planters also called upon the dyeing manager of a British-owned company, J. Scott, who was experienced in using synthetic indigo in the colony. Their primary argument was that natural indigo in the hands of a seasoned dyer, and used under actual dying conditions, provided more color. The planters were taking the battle to the home ground of synthetic indigo and to the market.

These trials returned consistently positive results in favor of agricultural indigo. Three pieces of serge of identical weight, length, and texture were dyed in two similar vats containing equal amounts of indigotin, using agricultural and synthetic indigo produced by BASF (Badische Anilin and Soda Fabrik), which was the first manufacturer of the artificial product. Bergtheil asserted in a report that "in each case the colour produced was considerably deeper and of a richer, 'bloomier' shade from the vat containing natural indigo." He surmised that the Cawnpore results indicated that natural indigo had "marked advantage" over the synthetic for dyeing woolen goods specifically. He emphasized that constituents other than indigotin present in the natural indigo had a definite role in imparting deeper color. This was in line with the planters' quest to reinsert a different economic, utilitarian valuation into the market, even when using the same percentage test that many planters had serious reservations about. ${ }^{29}$

\footnotetext{
28 Steven Shapin and Simon Schaffer, Leviathan and the Air Pump: Hobbes, Boyle, and the Experimental Life (Princeton: Princeton University Press, 1985).

29 Cyril Bergtheil, "The Dyeing Principle of Natural Indigo," Indian Planters' Gazette, 12 Jan. 1907: 53; "Natural versus Synthetic Indigo: Practical Dye Test," Indian Textile Journal, Sept. 1907 : 385; Report of the Indigo Research Station, Sirsiah, 1906-07 (Calcutta: Baptist Mission Press, 1907), 4-12, British Library, Oriental Collections, ST 1882.
} 
PLANTATION INDIGO'S RETREAT

The Cawnpore trial caught wide attention in indigo production and trading circles. A few who were familiar with the science of indigo manufacture, dye analysis, and dyeing applauded that "science is lending her invaluable, if belated aid" to the task of reviving plantation indigo. They were referring to the latest effort to align natural indigo science with the validation process of analytical tests. Among the din of voices that responded to Bergtheil's trials was that of J. Grossman, a dye chemist, fellow of the Institute of Chemistry, and long-time associate of the Society of Dyers and Colourists in Yorkshire, where he lived. Dye testing was his professional specialty and he saw himself as standing on the side of "science." He welcomed the latest trends in which, as displayed at Cawnpore, science seemed to be prevailing over "art"- standing for artisanal skill-in the plantation indigo industry.

Writing in Yorkshire's leading newspaper, the Manchester Guardian, Grossman expressed admiration for the recent emphasis on science in the manufacture and usage of agricultural indigo. Referring to Cawnpore trial, he belabored the point: "The recent controversy on indigo must have convinced the most skeptical that indigo dyeing is a science. And yet it is less than thirty years since it was considered an art." For Grossman, the Cawnpore trial had elevated the planters' commodity and craft, and symbolized the transformation of indigo production from "art" to "science." Grossman also indicated the path forward for natural indigo: "If we follow the development of any chemical industry, we shall find that its ultimate aim has always been to produce the purest article." If indigo planters made sufficient efforts to remove "the browns and glutens" from their product, they would produce an indigo "greatly resembling the artificial product" that would sell well. He asserted that the success of every contemporary industry depended on the "practical application" of scientific principles and that was the way to truly improve indigo. He surely had in mind the alliance of scientific research and industrial manufacturing that had emerged in the latter half of the century and was now evident across industrial landscapes from Germany to the United States. The German synthetic dye industry was a prime example. Grossman's comments about purity likely reflected his cognizance of organic chemistry's successes in mimicking the natural process of color production. A dyer himself, he had seen alizarin replace the red dye obtained from the roots of the madder plant, and now plantation indigo, too, was threatened by a synthetic. ${ }^{30}$

30 Several letters in the Manchester Guardian, including Grossman's, were reprinted in the Indian Planters' Gazette, 4 May 1907: 519-22. For the development of the field of organic chemistry, see Alan J. Rocke, The Quiet Revolution: Hermann Kolbe and the Science of Organic Chemistry (Berkeley: University of California Press, 1993). For applications of this new science in the dye industry in Europe, including Germany, see Anthony S. Travis, The Rainbow Makers: The Origins of the Synthetic Dyestuffs Industry in Western Europe (Bethlehem, Pa.: Lehigh University 
At the Cawnpore demonstration Cyril Bergtheil had presented planters' arguments in terms acceptable to analytical chemists and traders. He had interceded on the planters' behalf in the world of the "new" science and market. Though Grossman rejected Bergtheil's belief in the dying utility of nonindigotin elements, both men placed indigo within a specific vision of science and industrial progress and wanted to move agricultural indigo production into a new paradigm that was in step with the march of quantified science and market rationalization. ${ }^{31}$

But there were others who wanted to persist with the older ways of determining indigo's market value and its place in the world. A few planters distanced themselves from the "rationalizing" paradigm advocated by the likes of Grossman and Bergtheil. Some of this opposition expressed what was almost an aversion to "science" as it became a sign of the rationalizing system that threatened to exclude "natural" indigo. Sometimes they attacked the consensus seen to exist between scientists, including planters' own scientists, and the norms followed in the trade. Some planters charged scientists with giving tacit approval to the "centage test," which they believed discriminated against natural indigo. One planter wrote in the Gazette that planters had surrendered ground to this inimical science by having hired Bergtheil, who believed in the test and had betrayed them to the other side. This critic called for a complete rejection of the testing system in order to restore indigo's past glory, and said the planters "were infatuated enough to select a 'centage tester as their chemist, and with still more infatuation are selling their indigo in Calcutta on a 'centage test, and so playing directly into the hands of the synthetic people...."32 These were the planters who wanted to renounce the system completely and continue the scientific program to improve indigo according to a separate set of criteria.

\footnotetext{
Press, 1993). For the rise of the German synthetic dye industry and its monopoly over the world trade in dyes, see John J. Beer, The Emergence of the German Dye Industry (Urbana: University of Illinois Press, 1959); Werner Abelshauser, Wolfgang von Hippel, Jeffrey Allan Johnson, and Raymond G. Stokes, German Industry and Global Enterprise, BASF: The History of a Company (Cambridge: Cambridge University Press, 2009). For the beginnings of the dye industry in the United States, see Kathryn Steen, The American Synthetic Organic Chemicals Industry: War and Politics, 1910-1930 (Chapel Hill: University of North Carolina Press, 2014).

31 These might be characterized as what the sociologists of science Trevor Pinch and Wiebe Bijker have called "orderly" disagreements among scientists. They argue that orthodoxy and heterodoxy conceal a more radical philosophical censorship in scientific practice. Their characterization of the norms of science can be extended to our purposes of distinguishing what counted as science/modern and what as non-scientific/non modern. Trevor J. Pinch and Wiebe E. Bijker, "The Social Construction of Facts and Artifacts: Or How the Sociology of Science and the Sociology of Technology Might Benefit Each Other," in Wiebe E. Bijker, Thomas P. Hughes, and Trevor J. Pinch, eds., The Social Construction of Technological Systems: New Directions in the Sociology and History of Technology (Cambridge: MIT Press, 1995), 17-50.

32 Indian Planters' Gazette, 7 July 1906: 27.
} 
The dyer Alexander Playne, of Dunkirk Mills in Gloucestershire, similarly challenged the basic premise of the percentage test, and the "fallacy" that more color could be obtained from synthetic indigo. He claimed to have "repeatedly appealed to the chemists to show me how to get the 40 per cent more colour they say is in indigotin than in indigo," but had failed to elicit any response. He pitted the practical skills of a dyer against the assertions of formalistic science. ${ }^{33}$ Playne spoke for the old order and put forward its strongest traits: skill, practical experience, and artistry. Despite his personal tenacity, the natural indigo loyalists he represented were a rapidly shrinking class. For a long time he offered to hold a public demonstration in the metropolis that would reveal the better returns agricultural indigo offered. Some planters, such as W. Hudson and L. MacDonald, helped fund his efforts. Writing in several journals, Playne challenged anyone to prove in a public contest that dyeing with synthetic indigo was cheaper. Yet there were indications that actors like Playne were becoming irrelevant, and the competition paid his challenges little heed. With their dominance so established, they saw no need to respond to dissenting voices.

The planters and their supporters who spoke in this radically different voice embodied and signified wider historical currents. They represented a rich repertoire of opinions among planters with the potential to push back the advancing rationalizing forces, and they projected an alternative paradigm and cultural consciousness. They saw that the new science and standards for evaluation and consumption would ultimately subvert the production of indigo on plantations. To accept the reductive analysis of the dye would spell doom for "natural" indigo's future. To abandon the aesthetic criteria of uniqueness and originality to even a qualified embrace of quantitative evaluation and values would concede tactical ground, and be a retreat from the position from which agricultural indigo could be most forcefully defended. These critics realized that natural dye could never win the battle against synthetic indigo on the basis of purity and consistency. It is important to distinguish such voices from the larger collective of natural indigo backers since they represented both a unique set of historical forces and a distinct and unified alternative philosophy. They staked their claims for attention within broader historical discussions about the emergence of reductive scientific paradigms of nature and life, visions of progress associated with them, and anxieties about their pervasiveness.

The Cawnpore trial, in a way, marked the moment of the planters' retreat. The public spectacle registered their failure to attribute a different meaning to their commodity and thereby redefine its worth. The natural dye's former meaning and utility had been destabilized by the synthetics, and to counter

33 Indian Planters' Gazette, 30 June 1906: 768-69; 13 Mar. 1909: 345. 
this, the planters strove to alter the relationship between consumers and their product, inserting an aesthetics based on "natural" indigo's unique qualities. The trial at Cawnpore singularly failed to do this.

METROPOLITAN POWER AND THE COLONIAL LOCATION OF PLANTATION INDIGO

At the outbreak of the First World War in 1914, new scientific efforts were launched to bring changes to the constitution of agricultural indigo in the colony. The wartime scientific program to change the natural dye marginalized plantation indigo, partly on account of its location in the colony. As the agenda was set, a clear hierarchy of interests was in play, with those of the metropole trumping those of colonial Europeans. The forceful intervention of metropolitan actors and the relative powerlessness of planters, including the critics of rationalizing change just discussed, were stark. The latter's ideas were disregarded as the metropolitan forces closed ranks to transform the agricultural-dying endeavor.

In the years following the Cawnpore trial the fortunes of agricultural indigo continued to slide. The colonial plantation industry saw many European planters switch to other pursuits, and the last experimental station devoted exclusively to indigo research, at Sirsiah, closed at the beginning of $1913 .{ }^{34}$ The war revived the hopes of those in the industry when German supplies of synthetic indigo to the metropolis dwindled and British dyers and printers demanded that the colony's plantation industry be revived. ${ }^{35}$ Accordingly, resources were allocated for producing the agricultural dye within a new model of improvement.

\section{The Delhi Conference}

The war's outbreak was an important moment in the efforts to determine the future of the natural dye, and crucial in cementing a lasting definition of what natural indigo was and should or could be. Plant indigo backers sensed an opportunity to revive the imperial garden of indigo plantations and implement what they had always believed in: the superiority of "colonial improvement" over synthetic industrialism, potency over industrial efficiency, and their science over that of synthetic chemistry.

34 Report of the Indigo Research Station, Sirsiah, 1912-3 (Calcutta: Baptist Mission Press, 1913), 2, British Library Oriental Collections, ST 1882.

35 Germans had maintained a monopoly over synthetic indigo through the war years, retaining the dependence of all the major textile manufacturing nations. Efforts to manufacture synthetic indigo elsewhere in Europe and in the United States proved futile. Before the war the Germans had gone out of their way to guard indigo manufacturing secrets. During the war, however, English manufacturers started making indigo after they confiscated Hoechst's plant in Manchester. Not until the war's end did synthetic indigo reach American markets from American and nonGerman sources. I owe this information to Kathryn Steen of Drexel University. 
The advocates of plantation indigo also saw opportunity in the revived political attentions toward their crop. For once, metropolitan interest in the indigo garden and colonial interests coincided and mutually reinforced each other. Some, like William B. Bridgett, the proprietor of the East India Indigo Company in London, revived their charges that the percentage testing system was unfair to agricultural dye and had brought the natural indigo industry to its current ruinous state. ${ }^{36}$ Bridgett was trying to resurrect the old debate about natural indigo's authenticity, which had been sidelined for some time. Though agricultural indigo supporters found in the outbreak of war a chance to reassert their vision, the moment would prove to be fleeting.

Another advocate, baronet and former indigo planter John Lewis Hay, in an effort to revive indigo dye in Bengal publicized a radically different, romantic vision of it. In a series of letters to the secretary of state, the highest official in the metropolitan wing of colonial administration, Hay asserted that a unique, holistic relationship existed between the indigo plant, its surroundings, and the plant's internal processes. Though some found his views fanciful, he managed to draw attention to his theory. He followed the German Romantic Goethe's anti-Newtonian stipulations on the nature of color, arguing that the indigo plant received energy from sunlight and stored it within for future use. ${ }^{37}$ Hay put special emphasis on sunshine as the source of a special form of energy and on the role of hairs on indigo leaves in capturing that energy. As a planter in India, he had diligently recorded changes in indigo liquor's color as it passed through various stages of manufacturing. On the basis of those observations he had prepared "color charts" that he now disseminated, hypothesizing that the color changes represented chemical changes. His analysis led him to infer that the current process of manufacturing on the plantations was wasteful. He suggested the yield of agricultural dye could be increased without compromising its basic character. ${ }^{38}$

36 Trader W. B. Bridgett's "confidential" letter to the Viceroy and the Secretary of State, 9 Sept. 1914, letter 3028, serial 13, no. 40, Government of India, Proceedings of the Department of Revenue and Agriculture for March 1915, India Office Records, Government of India, Proceedings, Revenue \& Agriculture, P/9726, British Library (henceforth cited as PDRA with date and file number). Bridgett, a trader of indigo for the previous thirty years, wrote to the secretary of state asking him to do all that he could to revive the natural indigo industry. Bridgett readily perceived that the breakdown in German supplies of synthetic indigo created an opening.

37 Romantic sensibilities have been associated with philosophies in the post-Industrial Revolution period, and identified as a state of mind across different places and times. David Knight, "Romanticism and the Sciences," in Andrew Cunningham and Nicholas Jardine, eds., Romanticism and the Sciences (Cambridge: Cambridge University Press, 1990), 13-24.

${ }^{38}$ Hay captures our attention for his romantic theory in the World War I era. While he was allied with metropolitan chemists in trying to get indigo trials restarted in colonial India, he differed with them in his ideas about how color was produced and stored within plant indigo. The clash of his theory with those of professional chemists sometimes became clear, as in his conversations with the metropolitan natural dye chemist A. G. Perkin. His hypothesis on color changes ran against Perkin's findings from formulaic chemistry. Perkin said he was unable "to account scientifically or to advance a theory" for Hay's observations. He also disagreed with Hay's hypothesis giving 
The colonial government, spurred by the metropolis, convened the Delhi Conference in 1915 to discuss the future direction of experiments with natural indigo. Attendees, including planters, government officials, and trade representatives, sought to reach a consensus on how best to improve agricultural dye so it not only met immediate imperial needs, but would also be a viable commodity after the war, when the competition with synthetic indigo resumed.

The conference was an important venue where the likes of Hay, Bridgett, and Playne, and the planters as a class, could make a pitch to preserve the integrity of the plantation manufacturing system and the commercial viability of the natural dye. All of them did indeed participate and freely aired their views, suggesting a way forward that would not fundamentally disrupt the dye's identity as an agricultural, plantation product. And yet by the end of the conference such opinions had been marginalized. Bridgett's attack on the fundamentals of the system of international trade, pricing, and competition was simply dismissed as partisanship, and overall such views were rebuffed in favor of those advocated by commercial dyers and printers.

Bernard Coventry, Director of the Imperial Agricultural Institute, colonial India's foremost agricultural center, at the conference proposed a radically different plan for indigo experiments, one that echoed calls made by important wartime chemists in the metropolis. He began by calling for a series of experiments in chemical laboratories to find ways to make natural indigo in a form that could be sold like synthetic indigo was. Chemistry had already been deployed in the colony to make vat processes more efficient and to purify the dye in its final form, but the new plan envisioned using chemistry to transform natural indigo into a replica of synthetic indigo, as the commercial users desired. It was widely believed in imperial-colonial circles that natural indigo had to be adapted to current user preferences if it was to remain viable as a product. Coventry suggested producing plant-derived indigo in a standardized strength, containing a fixed percentage of indigo. His plan asserted that a predictable strength would enhance the agricultural dye's usability. Coventry's plan put forth well-publicized views of Henry E. Armstrong, an influential wartime chemist in Britain and a professor of chemistry at Central Technical College in London, who had laid out the exact same plan to save the colonial natural indigo industry. Armstrong was highly placed in British Government policy-making circles, and the secretary of state and his officials at India House had recently sent him to India to advise planters on how to

a place to "sunshine" in the decomposition of substances in the vat. A. G. Perkin's letter to Lewis J. E. Hay, 14 May 1913, encl. in letter from Francis C. Drake, Secretary, Revenue and Statistics, India Office, to Secretary, Revenue and Agriculture, Government of India, 6 June 1913, letter no. R\&S 1891, serial no. 3, no. 57, PDRA, Sept. 1913, P/9215. 
resurrect the natural indigo. Metropolitan and colonial elements seemed to be joining forces to chart a course of development for indigo dye.

Coventry's perspective carried the day and became the lasting paradigm for indigo improvement in the last round of "improvement" in the colony. He effectively challenged the dissenters with statistics showing that 90 percent of the world's dyers and printers had switched to synthetic indigo. The dissenters were unable to make a case for retaining the agricultural dye's basic attributes, and were either sidelined or brought over to a view that the agricultural dye's salvation lay in eliminating specific characteristics such as its variable constitution, and others that dyers and printers perceived as inferior. The agricultural dye, "a product of nature," would have to undergo basic changes to its identity. ${ }^{39}$

\section{Metropolitan Power and Rationalization}

Some planners in the colony, and a few of their supporters in London, still supported improving agricultural indigo on its own terms. This idea found maximum traction among "colonial" actors caught up in local colonial power relations. If one considers indigo dye to be "colonial" because its production was influenced by colonial conditions, then one could aver that the planters' defense of the agricultural dye was also colonial in nature. But it was the metropolitan forces that were positioned to dictate terms, and they favored turning the agricultural dye into a duplicate of the artificial product.

The demand for a market-friendly science and rationalization was further reinforced at a follow-up conference at the India House organized in London to which planters, traders, and metropolitan chemists were again invited. Most prominently at this conference, the chemists Henry Armstrong and A. G. Perkin, the latter a leading expert on natural dyes, from Leeds, supported demands that natural indigo be produced in a manner like the synthetic product. This involved turning the dye into a standardized paste that was uniform from batch to batch. Armstrong argued that to produce a standardized paste the planters would have to set up a centralized factory, or a few factories, to which they would forward their indigo in a semi-manufactured state. At these factories the raw product would be assessed for indigotin, bulked, standardized, and made into a paste ready for export.

The planter representatives at the meeting expressed reservations about rationalizing an agricultural operation along "modern [industrial] lines" that mimicked the production and distribution of synthetic indigo. Most had qualms about how plantation manufacturing would be centralized. Planter Martin T. MacDonald was unsure if planters could be induced to cooperate

\footnotetext{
39 Appendix A, "Note on Indigo Research in India," by Bernard Coventry, pp. 9-10, "Memorandum of Proceedings of the Indigo Conference Held at Delhi on 22nd February 1915," no. 44, serial no. 17, PDRA, Apr. 1915, P/9726.
} 
with the new regime of production and especially with the proposed changes in distribution and sales. Retired planter John Lewis Hay doubted that his former colleagues would be able to collaborate to have their dye centrally processed. A third planter, C. B. Gregson, was more amenable on the issue of organization, provided that the government gave some sort of financial guarantees. To those planters who expressed misgivings about industry-wide organization, Armstrong curtly responded that they had no other option. Posturing himself as the British government's spokesman, he declared in no uncertain terms that unless the planters would cooperate to produce standardized paste government assistance was ruled out.

Those who favored producing agricultural indigo in the new commoditized form received further backing when a major body representing English consumers demanded that planters supply indigo to the English markets in a standardized paste. In a significant public meeting held on 20 November 1915, members of the Foremen Dyers' Guild, England's largest organization of dyers, gathered to discuss disruptions to the supply of German synthetic indigo. Their president, Rowland E. Oldroyd, launched a scathing attack on the planters for their insensitivity to needs of users in the metropolis. The dyers, too, wanted the revitalized colonial plantations to supply indigo dye as a standardized paste and thus bring the trade in line with current trends of commercial use. Their meeting ended with a resolution imploring the planters in India to start making the paste. They approached the secretary of state directly with their demand and quickly drew interest from the India House, which apparently was open to the idea of administrative intervention to shape the market to metropolitan consumers' liking. ${ }^{40}$

The secretary of state was in complete agreement with these calls. He communicated to the planters his desire to support indigo commodification along the lines firmed up in the metropolis. He also warned that the financial support was conditional on planters reorganizing their entire industryincluding the organization, production, and distribution to make indigo paste - within a year. He said he was aghast to learn that the planters were still conducting their business "on old lines." The planters fell in line by accepting the offer of scientific support for making standardized paste and agreeing to move toward industrywide reorganization. ${ }^{41}$

40 Secretary of Foremen Dyers' Guild letter to Sir William P. Byles, 25 Nov. 1915; Report, Natural Indigo: A Chat to the Dyers' Guild by the President;" R. E. Oldroyd letter to Secretary of State, 17 Dec. 1915, no. 37, serial no. 1, PDRA, May 1916, Z/P/1980.

${ }^{41}$ Letter from BPA to Secretary, Revenue and Agriculture, Government of India, 7 Jan. 1916, no. 16, serial no. 10, PDRA, May 1916, Z/P/1980; letter from BPA General Secretary J. M. Wilson to Secretary, Revenue and Agriculture, Government of India, 13 Mar. 1916, no. 22, serial no. 16, PDRA, Z/P/1980. 


\section{A "Natural" Limit to Improvement?}

Indigo had by now undergone several rounds of improvement, but this one was the most invasive in its intent to completely transform the commodity. The goal of the project of metropolis-backed improvement was to change the dye to resemble its competitor. For a number of years planters had tried to maintain their product's separate identity and remained sensitive to the suggestion that synthetic indigo was a legitimate substitute. The foundation of their effort had been to differentiate the two, and now they were being pushed to do precisely the opposite. That the scientists' plan to change agricultural dye in the image of synthetic indigo was the right thing to do had already been decided by the dominant opinion of consumers and metropolitan chemists. What remained to be seen was whether it was feasible. Events would show that the rationalizers had overestimated their capacity to appropriate agricultural indigo to their designs.

It seemed that nothing the rationalizers tried offered hope for a turnaround in natural indigo's fortunes. Or was the real problem that the agricultural dye was resisting its transformation into a factory-like product? ${ }^{42}$ A first barrier was reached when planters realized the extravagancy of sending the dye in 20 percent concentration to England, thus paying freight for three times the weightage they had paid on a dye that was in 60 percent concentration, and at a time when freight charges were skyrocketing due to the war. ${ }^{43}$ The response was to move the paste-making enterprise to England. Armstrong, the paste program's guiding force, initially reported that they had successfully fabricated a paste form of agricultural indigo and that English dyers liked the specimens presented them. It was claimed this paste could compete with the synthetic indigo that English factories like Levinstein and Company had recently begun to supply. But Armstrong's more market-oriented approach to improving the commodity encountered an untimely setback in 1918-1919 when crops perished in Bihar due to bad weather and the price of indigo consequently soared in the Calcutta market. As a result, planters found it more profitable to sell their indigo there rather than send it to faraway London. Thus, despite repeated requests from the Paste Committee in London (which had been formed to supervise paste-making), no indigo reached England and the work of the metropolitan chemists stopped. Armstrong's scientific solution had run

\footnotetext{
42 The subject of the "limit" set by nature or the natural order is pervasive, found in many historical accounts. The theme of a "limit" has been posed as an external, absolute limit on social action, and as a constructed limit. Environmental historian Richard White has conceded that nature can set limits to social action, arguing in an important review essay, "Nature does not dictate, but physical nature does, at any given time, set limits on what is humanly possible"; "American Environmental History: The Development of a New Historical Field," Pacific Historical Review 54 (1985): 297-335, 335.

43 J. M. Wilson's letter to L. T. Harington, 6 Dec. 1916, no. 109; Harrington's reply of 26 Mar. 1917, no. 36, PDRA, Aug. 1917, Z/P/1981.
} 
up against the logic of prices in the local market in the colony. Put another way, the logic of agricultural production and the old market was proving resistant to the imposition of a new order of manufacturing. ${ }^{44}$

The war-induced, metropolis-driven, consumer-inspired indigo science failed to change natural indigo's destiny. As the possibility that English companies could manufacture synthetic indigo started becoming a reality, India House lost interest in the workings of the committee in London. The best efforts of science and rationalization to develop the agricultural dye into a product competitive with synthetic indigo made in the metropolis had failed. This reality became crystal clear to the backers of the colonial dye at the end of the war, as English manufacturers enthusiastically began producing synthetic indigo for the home market and dyers, printers, and users eagerly chose the synthetic dye if it was available. The metropolis-inspired effort to make natural indigo stand on its own was abandoned in the face of a general consensus that the improvement of the product had reached a natural limit. But this was a limit reached while traveling a path to "improvement" that had been plotted by vested interests.

\section{CONCLUSION: A NEW INDUSTRIALISM?}

The planter response to the threat of synthetic colors was both economic and cultural in nature. Most were forced to compromise in the face of sweeping structural forces ushering in a new, science-based industrial world. The voices of accommodation agreed to change natural indigo dye to resemble the competition, even as they tried to oust the competing product. But on the flanks of the more general response of compromise, another worldview among a section of planters and their supporters advanced a more radical critique of emergent science-based industrialization. Their response was to try to save agricultural indigo partly by shifting the criteria for its appreciation and valuation away from objective, measurable standards. To arrest the slide toward utilitarian mass consumption, they sought to recover links that had previously existed between "taste and reason, connoisseurship and utility, and sensibility and scientificity." 45 This perspective was not a simple hankering for the past or flatly anti-industrial; rather, those who held it were resisting the ongoing, brute ordering of production and consumption epitomized by the synthetic industry.

\footnotetext{
44 Moran and Company letters to Paste Committee, 28 Aug. 1919, 13 Nov. 1919; letters from Paste Committee to Moran Company in India, 16 Oct. 1919, 20 Nov. 1919; letter from Indigo Paste Committee to the Under Secretary, Revenue Department, India House, 25 Nov. 1919, PDRA, May 1920, P/10846.

45 Emma Spary describes the eclecticism that marked eighteenth-century valuations of commodities and things in terms of an "ensemble of binaries," which faded away in the nineteenth century; "The 'Nature' of Enlightenment," in William Clark, Jan Golinski, and Simon Schaffer, eds., The Sciences in Enlightened Europe (Chicago: University of Chicago Press, 1999), 273.
} 
The objections of agricultural indigo's backers to its transformation under the norms of the second industrial revolution were deep and recurring. One leading light of the program to commodify agricultural indigo, Armstrong, became conflicted on the issue. Even after the paste-making program faded away he remained a strong supporter of efforts to revive the natural indigo industry. But he also changed his views of natural indigo. In a letter to the Times of London in 1920, he wrote, "The Germans are not to be credited with the production of indigo, but only with having made its chief constituent.... While nature, assisted by man, gives us indigo, [industrial] art gives us but one of the constituents, indigotin." 46 Having tried and failed in making agricultural indigo pure and consistent, Armstrong apparently came to believe that it was a product of nature and should be valued for such attributes as nature gave to it.

Toward the overall quest for industrial modernity the planters had been ambivalent at best. They had enjoyed a cozy relationship with factory production through most of the nineteenth century, and their blue dye smoothly rode out the transition from artisanal to factory manufacturing in textile production and continued to dominate dyeing and printing. Indeed, the nineteenth-century expansion of indigo dye production was the result of an explosion in textile manufacturing. But that market capitalism was taking new forms was particularly evident in businesses like the synthetic dye industry. A marked feature was science-enabled mass production for a substantially broadened market of consumers. In the nineteenth century's second half a plethora of new cheaper and easier-to-use colors were being marketed and sold at the same time as textilemanufacturing was spreading into new zones. ${ }^{47}$ This change in the course of manufacturing by and large severed industrial production's links to agricultural hinterlands. Dye manufacturing typified an ever-growing trend toward producers sourcing raw materials from within the factory walls. Industrial forces had decided to depend on science rather than wrestle with the irregularities of agricultural production and the peculiarities of agricultural commodity production. They discarded their previous, visceral fascination with the fundamental traits of agricultural commodities.

References to nature notwithstanding, planters' resistance did not express an ethic of de-commodification. They had always dealt in a commodity and had built their fortunes by commodifying a product of nature. The target of their critique was the manufacturing process, and their rebellion was against industrial capitalism's scientific turn. This turn had enabled revolutionary changes in

\footnotetext{
46 Henry Armstrong, “The Indigo Industry: Revival Assured, Letter to the Editor," the Times, London, 8 Apr. 1920: 6.

${ }^{47}$ For the expanding domain of synthetic dyes in the latter half of the nineteenth and the early twentieth centuries, along with the increasing numbers of the dyes and their consumers, see John J. Beer, The Emergence of the German Dye Industry (Urbana: University of Illinois Press, 1959).
} 
markets and production, and the planters had to keep certain things out of the new industrialism if they wished to survive. They were anxious about the marauding second wave of industrialization that was excluding agricultural products from more and more regions. Their conception of the proper alignment of society and economy was quite different from that favored by the synthetic dye industry. Isolated and forlorn on the colonial plantations, betrayed by global changes in textile manufacturing and the recent turn of British metropolitan politics, European indigo planters confronted the new face of modernity emanating from the marriage of science and industrialization.

\begin{abstract}
As the nineteenth century drew to a close, European planters manufacturing indigo on colonial plantations in Bengal faced a major challenge from synthetic indigo. Synthetic indigo was a symbol of the successful integration of chemistry into industrial manufacturing that had occurred in the second half of the century, and it threatened to displace the colonial commodity. It also fundamentally challenged the colonial program of "improvement" that agricultural indigo represented, and the mode of production consisting of stewardship of plants and the extraction of a commodity within the plantation system. The planters pushed back on the synthetic product by emphasizing the merits of agricultural indigo. As part of this resistance, they claimed that the plant-based dye was "natural" and superior because it was produced through agriculture, and they pointed to the grounding of their methods of production in the layout of land and farming. They argued that when setting their product's value the market should give weight to its unique attributes and the extraordinary quality that nature had bred into the dye. This study reads in this response a critique of the growing ties between manufacturing and science and technology. The planters' critique was not a straightforward critique of the vicissitudes of market, but rather a fight to retain a place for the sort of exchanges and value that plant indigo growers were accustomed to dealing in. They viewed plantation manufacturing as wholesome and organic, and defended it in the name of nature.
\end{abstract}

